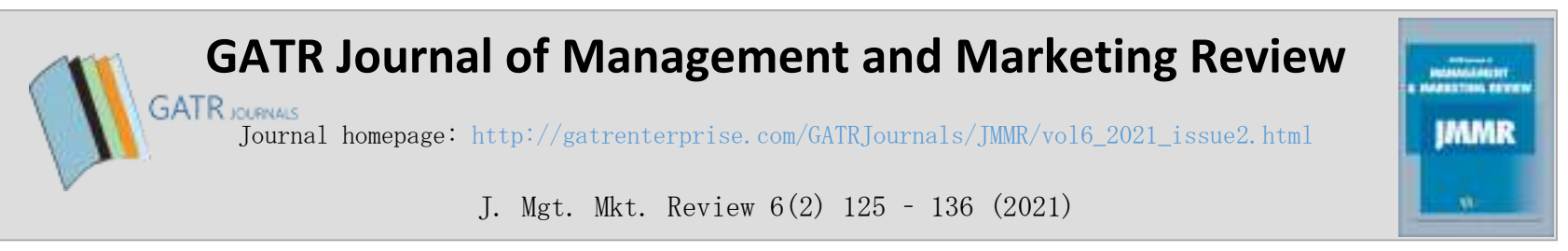

\title{
Double-Sided Perspective of Business Resilience: Leading SME Rationally and Irrationally During COVID-19
}

\author{
Nopriadi Saputra $^{1 *}$, Maria Grace Herlina ${ }^{2}$ \\ ${ }^{1,2}$ Management Department, BINUS Business School, Undergraduate Program, \\ Bina Nusantara University, 11530, Jakarta, Indonesia
}

\begin{abstract}
Objective - This study aims to elaborate business resilience of small medium enterprises and to test the impact of rational and irrational antecedents of business resilience during COVID-19 crisis.

Methodology/Technique - It is cross-sectional and causal study for testing five hypothesizes. Convenience approach was used as non-probabilistic sampling method. It involved 506 small medium enterprises in Jawa and Sumatera, the biggest islands in Indonesia. Collected data were structured with PLS based Structural Equation Modelling.

Findings - The result explained that business resilience is influenced positively, directly, and significantly by business flexibility and workplace spirituality. Business flexibility is influenced by workplace spirituality, pro-social leadership, and alliance capability. Pro-social leadership of owners and/or managers influences implementation of health protocol and alliance capability.

Novelty - This study has proved that business resilience has both sides of antecedents - in rational and irrational perspectives.

Type of Paper: Empirical.

JEL Classification: L26, L29.

Keywords: Business Resilience, Small Medium Enterprise

Reference to this paper should be made as follows: Saputra, N; Herlina, M.G. (2021). Double-Sided Perspective of Business Resilience: Leading SME Rationally and Irrationally During COVID-19, J. Mgt. Mkt. Review, 6(2) 125 - 136. https://doi.org/10.35609/jmmr.2021.6.2(4)
\end{abstract}

\section{Introduction}

Global crises that have had major impacts on SMEs have happened several times, such as the great depression in the 1930s, the financial crisis at the end of the 1990s and, more recently, COVID-19 pandemic as the trigger of global crisis (Tsilika, Kakouris, Apostolopoulos, \& Dermatis, 2020). COVID-19 forces more than 200 countries to discontinue infection spread through border closures and social distancing. Those practices have led to business failures and the consequent job-losses that particularly affect SMEs (Castro \& Zermeño, 2020) and causing serious collapse (Beninger \& Francis, 2021). It has created an unforeseen crisis for SMEs (Păunescu \& Mátyus, 2020).

\footnotetext{
* Paper Info: Revised: March 12, 2021

Accepted: June 30, 2021

* Corresponding author: Nopriadi Saputra

E-mail: nopriadi.saputra@binus.ac.id

Affiliation: BINUS Business School, Bina Nusantara University, Indonesia
} 
Empirical study which involved more than 5,800 small businesses in USA reveals that COVID-19 has impacted on small businesses with (1) mass layoffs and closures, (2) risk of closures, (3) financially fragile, and (4) seeking funding through CARAS Act (Bartik, Bertrand, Cullen, Glaeser, Luca, \& Stanton, 2020). In the developed countries such as in European Union, SMEs account for a striking $99.8 \%$ of all employer firms, $65 \%$ of private sector employment and $54 \%$ of private sector gross output (Gourinchas, KalemliÖzcan, Penciakova, \& Sander, 2020). In developing country like Indonesia, there are 63 million SMEs which contribute $60 \%$ of gross domestic product (Surya, Menne, Sabhan, Suriani, Abubakar, \& Idris, 2021). These facts indicate that SME plays an important role in the global and national economy. Something happening to SMEs will make a huge impact on economics nationally and globally. As a rapidly growing disturbance, COVID-19 forces SME to become as resilient as possible in maintaining operations and protecting employees (Aldianto, Anggadwita, Permatasari, Mirzanti, and Williamson, 2021). The trans-boundary disturbance of COVID-19 brings an unprecedented test for SME resilience (Bryce, Ring, Ashby, \& Wardman, 2020). The term of resilience is an emerging concept that is used for elaborating alertness and economic performance to the extreme changes such as financial recessions and crises (Castro \& Zermeño, 2020).

Business resilience is a strategic and relevant issue to be discussed for two main reasons. First, business resilience is synonymous with persistence, self-efficacy, preparedness, or hardiness, to explain why some SMEs perform better than their non-resilient peers. Second, it is related to the ability of SMEs to adjust to new circumstances and to become sustainable in long-term (Korber \& McNaughton, 2017). During the crises, entrepreneurs as owners and managers of SMEs do everything - rational and irrational things for keeping their business sustainable. It is relevant with paradox theory which explain that in increasingly global, complex, and fast-paced world, competing demands on individuals, teams, and organization continually surface in the context of organizational life (Waldman, Putnam, Miron-Spektor, \& Siegel, 2019). During COVID-19 crisis, SME as organization and entrepreneur as individual are forced to do paradox things which are contradictory yet interrelated opposites that exist simultaneously (Cunha \& Putnam, 2019). Those are rational and irrational things.

Based on a systematic literature reviews, Castro and Zermeño (2020) has identified that business resilience can be developed by improving resilience of entrepreneurs as owner and/or managers of SME in five areas: (1) attitudes adopted toward the crisis, (2) fitness of business-entrepreneur characteristics, (2) relationships with institutions, (3) human and social capital and (6) strategic management. This study tries to elaborate and test impact of rational and irrational factors on business resilience. Rational factors cover business flexibility, alliance capability, and implementation of COVID-19 health protocol. Meanwhile, irrational factors include pro-social leadership and workplace spirituality.

\section{Literature Review}

\subsection{Business Resilience}

Resilience comes from the Latin word "resiliere" that means bounce back (Sabatino, 2016). It originated from the area of ecology which is defined as the ability of a system to returning to stability after a shock (Holling, 1973). Now, resilience term has been used in various fields, such as disaster management, engineering, psychology, sociology, and business administration (Korber \& McNaughton, 2017). A resilient organization will always be able to find out the ways to take chances and take advantage on any kind of situations (Aldianto et. al, 2021). Resilience is defined as the collective ability of an organization to cope with turbulences caused by external factors and remain unaffected. (Kurtz \& Varvakis, G, 2016). Păunescu and Mátyus (2020) defined business resilience as an organization capability to maintain its resources at a steady level by getting rationalized and being self-supported if a disruptive event occurs. Păunescu and Mátyus (2020) reflected business resilience into seventeen indicators. This study adopted nine items of those as indicators. 


\subsection{Business Flexibility}

In today's unpredictable environment, maintaining a competitive advantage with only one alternative has become a difficult and risky task for business firms. As a concept, business flexibility is a strategic capability for accessing various alternatives or optional mechanisms in freedom of choice on various processes (Jain, Kashiramka, \& Jain, 2020). It is similar to Volberda (1996) who defined business flexibility as the degree to which an SME has various options on managerial capabilities and the speed at which they can be utilized for improving business controllability. Business flexibility also emphasizes the flexible use of resources and freedom to reconfigure the processes and positively affects explorative innovation and new business development (Miroshnychenko, Strobl, Matzler, \& De Massis, 2020). Relating to SMEs' conditions during crisis, business flexibility is SME capability to find out various options of new businesses, new products, and/or market by reconfiguring business process and utilizing existing resources. This study used PIVOT concept (Libert, Beck, \& Wind, 2016) for measuring business flexibility which reflected into five dimensions and 14 indicators. Previous empirical study revealed that organizational flexibility plays a moderating role in relationship between data analysis capability and supply chain resilience (Dubey, Gunasekaran, Childe, Fosso Wamba, Roubaud \& Foropon, 2021). Another empirical study also revealed that supply chain flexibility as moderator on relationship between supply chain resilience and firm performance (Chunsheng, Wong, Yang, Shang, \& Lirn, 2019). Based on those empirical facts, this study supposes to test impact of business flexibility on business resilience.

H1: Business flexibility impacts on business resilience significantly.

\subsection{Alliance Capability}

When companies are smaller relatively to their competitors and to their market, they tend to use alliances to gain scope and economies of scale (Gomes-Casseres, 1997). The term of alliance capability has typically been stated in many labels such as collaborative capability, relational capability, or relational competence (Kohtamäki, Rabetino, \& Möller, 2018). Alliance capabilities refer to organizational ability to collect, distribute and maintain knowledge regarding collaboration management and to utilize the knowledge in existing and next collaborations (Niesten \& Jolink, A. 2015). This study reflects alliance capability into three dimensions (e.g., management, integration, and learning) and eight indicators (Kohtamäki, Rabetino, \& Möller, 2018). Previous studies revealed that alliance or collaborative activities influence supply chain resilience (Scholten \& Schilder, 2015; Medel, Kousar, \& Masood, 2020; Dubey, et. al., 2021). Based on the research, this study aims to test influence of alliance capability on business resilience.

H2: Alliance capability impacts on business resilience significantly.

\subsection{COVID-19 Health Protocol}

The Indonesian government declared the health protocol for inhibiting the spread of COVID-19 virus infection. Health protocols were guided centrally and instructed to be applied in all aspects of daily life (Kementerian Kesehatan, 2020). The protocol is a set of procedures for being disciplined ipracticing the principles of clean and healthy lifestyle by keeping distance, limiting physical contact, washing hands frequently, and wearing a face mask in daily life activities. It has been revealed in previous studies that physical health is associated with personal resilience. Osofsky, et al. (2019) found that decreased physical health was associated with resilience improvement. Ower, et al. (2019) concluded that physical activity was related with resilience positively. Swanson, Geller, DeMartini, and Fehon (2018) proved that physical functioning influences resilience significantly. Considering these empirical facts, this paper supposed to examine COVID-19 health protocol as health protection initiative impacts on business resilience. By considering the research, this study needs to examine the impact of health protocol on business resilience.

H3: COVID-19 health protocol impacts on business resilience significantly. 


\subsection{Prosocial Leadership}

During COVID-19, many entrepreneurs fight to keep their business operation for protecting their employees' family life rather than for concerning their own interests. Pro-social behavior of the entrepreneurs as owner and/or manager of SMEs is referred to as pro-social leadership in this study. Pro-social leadership is one of irrational practices for facilitating business resilience. During the crisis, most of entrepreneurs tend to be concerned about their own asset security rather than on pro-social leadership. Lorenzi (2004). Pro-social leadership is an effective and positive influence of a leader in actions aimed at meeting the needs of a larger group or social group rather than to personal interests. Pro-social leadership is willingness of the leader without regard to reward or punishment, to empathise and to do something for the welfare of his/her followers or society that he/she is committed to serve (Ewest, 2017). Previous studies have proved that leadership impact on resilience development. In China, an empirical study revealed that humble leadership develops employee resilience (Zhu, Zhang, \& Shen, 2019). A study which involved 40 Portuguese companies found that team resilience transformational leadership impact team resilience (Dimas, Rebelo, Lourenço, \& Pessoa, 2018). A study in a large New Zealand enterprise reveals that paradoxical leadership is as antecedent of employee resilience (Franken, Plimmer, \& Malinen, 2020). Referring the research, this study proposes to examine the influence of pro-social leadership on business resilience.

H4: Pro-social leadership impacts on business resilience significantly

\subsection{Workplace Spirituality}

Spirituality is perceived as irrational thing for entrepreneurs when they fight to keep their business in the crisis. It is assumed that workplace spirituality is not directly and logically relevant to building business resilience. It is getting a rising attention during the past decades, especially its effect on work performance (Petchsawang \& McLean, 2017). Spirituality is associated to a relinking to inner life and an appreciation of universal values that emphasize empathy for all living beings (Rezapouraghdam, Alipour, \& Arasli, 2019). Gatling, Kim, and Milliman (2016) explained that there are common themes on various definition about workplace spirituality are: (1) experiencing personal fulfillment and meaning at workplace, (2) having a sense of connection to others, and (3) aligning with the values of the workplace (Gatling et al. 2016). Previous studies have proved that there is a relationship between spirituality and resilience. Shelton, Hein, and Phipps (2019) concluded that people who are involved in meditative practices as spirituality development had a significantly better resilience score than non-meditators. Esievo, Oshi, Hettey, and Tende (2019) found a strong positive correlation between organizational resilience and workplace spirituality. Supported by the research, this study proposes to test the impact of workplace spirituality on business resilience.

H5: Workplace spirituality impacts on business resilience significantly.

\section{Research Methodology}

\subsection{Material and Method}

This study is a quantitative research with cross-sectional approach and using PLS SEM for casual analysis in hypothesis testing. It's about 506 owners and/or managers of SMEs in Indonesia involved as respondents. Convenience and snow-balling approach were used as sampling method. Based on literature review, the research model is demonstrated in Figure 1. Business resilience (BRES) is as dependent variable. Business flexibility (BFLX), alliance capability (COLA), COVID-19 health protocol (COVD), pro-social leadership (PROS), and workplace spirituality (SPRI) as independent variables. BRES was measured by nine indicators. BFLX was indicated by 14 indicators. COLA was reflected into eight indicators. COVD was described with 
nine indicators. PROS was defined into eight indicators. SPRI was constructed by 12 indicators. Figure 1 demonstrates the research model.

An online questionnaire-based data collection was conducted for sampling SMEs operating in two biggest islands of Indonesia (Sumatera and Java). The respondent are women (55\%) under 51-year-old (82\%). Most of them are highly educated persons with university educational background (74\%). They have direct control on the daily business operation. Most of them are managers and owner/managers (64\%). The scale of business is dominantly micro scale (with asset less than IDR 300 million or USD 20,000).

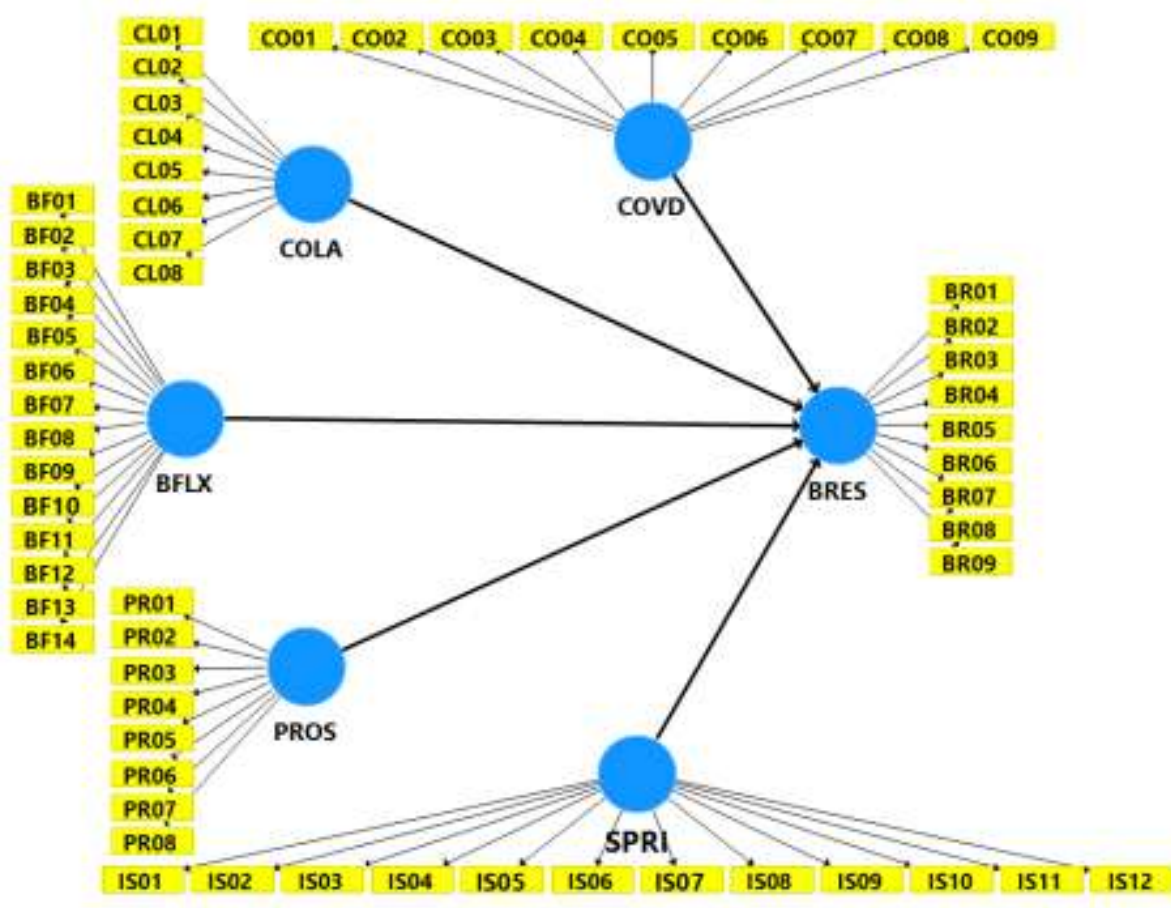

Figure 1. Research Model

Table 1. Profile of Respondents

\begin{tabular}{|c|c|c|c|c|}
\hline & ESPOND & & & \\
\hline \multirow{2}{*}{ Gender } & Male & 206 & $64 \%$ & $64 \%$ \\
\hline & Female & 115 & $36 \%$ & $100 \%$ \\
\hline \multirow{5}{*}{ Age } & $20-29$ & 76 & $24 \%$ & $24 \%$ \\
\hline & $30-39$ & 130 & $40 \%$ & $64 \%$ \\
\hline & & & & \\
\hline & $40-49$ & 67 & $21 \%$ & $85 \%$ \\
\hline & $50-$ up & 48 & $15 \%$ & $100 \%$ \\
\hline \multirow{3}{*}{ Education } & Diploma & 40 & $12 \%$ & $12 \%$ \\
\hline & Bachelor & 217 & $68 \%$ & $80 \%$ \\
\hline & Master & 62 & $19 \%$ & $99 \%$ \\
\hline
\end{tabular}




\begin{tabular}{|c|c|c|c|c|}
\hline & Doctor $/ \mathrm{PhD}$ & 2 & $1 \%$ & $100 \%$ \\
\hline \multirow{4}{*}{ Years of service } & up to 2 year & 17 & $5 \%$ & $5 \%$ \\
\hline & 3 - 5 years & 43 & $13 \%$ & $19 \%$ \\
\hline & $6-10$ years & 121 & $38 \%$ & $56 \%$ \\
\hline & More than 10 years & 140 & $44 \%$ & $100 \%$ \\
\hline \multirow{2}{*}{ Job Function } & Operation & 195 & $61 \%$ & $61 \%$ \\
\hline & Supporting Administration & 126 & $39 \%$ & $100 \%$ \\
\hline
\end{tabular}

Validity and reliability are conducted for assuring that research model was constructed by valid and reliable indicators and variables. Table 2 and Table 3 display the result of validity and reliability analysis. Outer loading (OL) score is used as parameter of valid indicator. Indicator with OL score less than 0.60 is excluded from the research model because it is invalid. BRES has five valid indicators. BFLX has eight valid indicators. SPRI has only four valid indicators. All indicators of COLA (eight items), PROS (nine items), and COVP (9 items) are valid. Average variance extracted (AVE) score in Table 2 and discriminant validity in Table 3 is used for validating the variables. A variable is valid if the AVE score is more than 0.50. All variables have AVE score more than 0.50. It means that all variables are valid.

Table 2. Validity and Reliability Analysis

\begin{tabular}{|c|c|c|c|c|c|c|c|c|c|c|c|}
\hline VARIABLES & ITEMS & $\mathbf{O L}$ & AVE & CA & CR & VARIABLES & ITEMS & OL & AVE & $\mathbf{C A}$ & CR \\
\hline \multirow{5}{*}{$\begin{array}{c}\text { Business } \\
\text { Resilience } \\
\text { (BRES) }\end{array}$} & BR05 & 0.63 & & & & \multirow{9}{*}{$\begin{array}{l}\text { COVID-19 } \\
\text { Health } \\
\text { Protocol } \\
\text { (COVD) }\end{array}$} & $\overline{\mathrm{CO} 01}$ & 0.74 & & & \\
\hline & BR06 & 0.75 & & & & & $\mathrm{CO} 04$ & 0.74 & & & \\
\hline & BR09 & 0.75 & 0.58 & 0.82 & 0.87 & & $\mathrm{CO} 03$ & 0.77 & & & \\
\hline & BR07 & 0.83 & & & & & $\mathrm{CO} 08$ & 0.78 & & & \\
\hline & BR08 & 0.84 & & & & & $\mathrm{CO} 02$ & 0.78 & 0.63 & 0.93 & 0.94 \\
\hline \multirow{8}{*}{$\begin{array}{l}\text { Business } \\
\text { Flexibility } \\
\text { (BFLX) }\end{array}$} & BF04 & 0.69 & \multirow{8}{*}{0.51} & \multirow{8}{*}{0.86} & \multirow{8}{*}{0.89} & & $\mathrm{CO} 05$ & 0.81 & & & \\
\hline & BF06 & 0.70 & & & & & $\mathrm{CO} 09$ & 0.82 & & & \\
\hline & BF07 & 0.71 & & & & & CO06 & 0.85 & & & \\
\hline & BF08 & 0.73 & & & & & $\mathrm{CO} 07$ & 0.87 & & & \\
\hline & BF09 & 0.67 & & & & \multirow{5}{*}{$\begin{array}{l}\text { Pro-Social } \\
\text { Leadership } \\
\text { (PROS) }\end{array}$} & PR05 & 0.68 & \multirow{5}{*}{0.60} & \multirow{5}{*}{0.90} & \multirow{5}{*}{0.92} \\
\hline & BF11 & 0.77 & & & & & PR06 & 0.69 & & & \\
\hline & BF12 & 0.77 & & & & & PR04 & 0.74 & & & \\
\hline & BF14 & 0.67 & & & & & PR03 & 0.76 & & & \\
\hline Alliance & CL05 & 0.80 & 0.70 & 0.94 & 0.95 & & PR01 & 0.78 & & & \\
\hline
\end{tabular}




\begin{tabular}{|c|c|c|c|c|c|c|c|c|}
\hline \multirow{7}{*}{$\begin{array}{l}\text { Capability } \\
\text { (COLA) }\end{array}$} & CLO4 & 0.80 & & PR02 & 0.82 & & & \\
\hline & CL01 & 0.82 & & PR08 & 0.83 & & & \\
\hline & CL08 & 0.83 & & PR07 & 0.85 & & & \\
\hline & CL07 & 0.86 & & IS01 & 0.73 & & & \\
\hline & CL02 & 0.86 & & IS07 & 0.74 & & & \\
\hline & CL03 & 0.86 & Workplace & IS04 & 0.77 & & & \\
\hline & CL06 & 0.87 & $\begin{array}{l}\text { Spirituality } \\
\text { (SPRI) }\end{array}$ & IS05 & 0.79 & 0.61 & 0.88 & 0.90 \\
\hline \multicolumn{3}{|c|}{$\begin{array}{c}\text { Note: } \text { OL }=\text { Outer Loading, AVE = Average Variance } \\
\text { Extracted }\end{array}$} & & IS08 & 0.81 & & & \\
\hline \multicolumn{3}{|c|}{$\mathrm{CA}=$ Cronbach's Alpha; $\mathrm{CR}=$ Composite Reliability } & & IS06 & 0.84 & & & \\
\hline
\end{tabular}

This validity result is strengthened by discriminant validity in Table 3. All diagonally bold scores (squareroot of AVE) are more than 0.70 and/or as the highest score in its column. It indicates that all variables are discriminant valid too. Cronbach's alpha (CA) or composite reliability (CR) scores are used for indicating reliability of a variable. A reliable variable has CA or CR score more than 0.70 . Table 2 shows that all variables have $\mathrm{CA}$ and $\mathrm{CR}$ scores more than 0.70 . It means that all variables are reliable. Based on validity and reliability analysis, it could be concluded that all indicators in Table 2 are valid and were kept in research model. All variables are valid and reliable. The research model is constructed by valid-reliable variables and valid indicators.

Table 3. Discriminant Validity

\begin{tabular}{ccccccc}
\hline VARIABLES & [1] & [2] & [3] & [4] & [5] & [6] \\
\hline \hline [1] Business Flexibility (BFLX) & 0,714 & & & & & \\
[2] Business Resilience (BRES) & 0,503 & 0,764 & & & & \\
[3] Alliance Capability (COLA) & 0,531 & 0,424 & 0,837 & & & \\
[4] COVID-19 Health Protocol (COVD) & 0,270 & 0,174 & 0,519 & 0,797 & & \\
[5] Pro-Social Leadership (PROS) & 0,493 & 0,394 & 0,764 & 0,475 & 0,771 & \\
[6] Workplace Spirituality (SPRI) & 0,265 & 0,232 & 0,215 & 0,267 & 0,275 & 0,781 \\
\hline \hline
\end{tabular}

\section{Results}

Hypothesis testing is based on t-Statistics or p-Values score of path coefficient in relationship among variables. A hypothesis is accepted, if path coefficient has t-Statistics score more than 1.96 or p-Value score less than 0.05. Bootstrapping calculation with subsamples 500 was conducted for this testing. The result is demonstrated in Table 4. From five hypothesizes, two hypothesizes ( $\mathrm{H} 3$ and $\mathrm{H} 4)$ are rejected and three hypothesizes $(\mathrm{H} 1, \mathrm{H} 2$, and $\mathrm{H} 5)$ are accepted. The result indicates that business resilience is influenced positively and significantly by business flexibility and alliance capability (as rational influential factors), and workplace spirituality (as irrational influential factor). Business resilience is not affected significantly by COVID-19 health protocol (as rational factor) and pro-social leadership (as irrational factor). This result 
provides us better understanding of business resilience. The antecedent of business resilient is double-sided. It could be influenced by rational and irrational factors.

Table 4. Hypothesis Testing

\begin{tabular}{cccccc}
\hline & Hypothesis & $\begin{array}{c}\text { Path } \\
\text { Coefficient }\end{array}$ & $\begin{array}{c}\text { t- } \\
\text { Statistics }\end{array}$ & $\begin{array}{c}\text { p- } \\
\text { Values }\end{array}$ & Result \\
\hline \hline H1: & Business Flexibility $==>$ Business Resilience & 0.365 & 7.958 & 0.000 & Accepted \\
H2: & Alliance Capability $==>$ Business Resilience & 0.177 & 2.833 & 0.013 & Accepted \\
H3: & COVID-19 Protocol $==>$ Business Resilience & -0.080 & 1.911 & 0.084 & Rejected \\
H4: & Pro-Social Leadership $==>$ Business Resilience & 0.104 & 1.327 & 0.102 & Rejected \\
H5: $\quad$ Workplace Spirituality $==>$ Business Resilience & 0.092 & 2.471 & 0.011 & Accepted \\
\hline \hline
\end{tabular}

\section{Discussions}

Business flexibility is directly influenced by business resilience. This result supports the finding of Dubey et.al. (2021) and Chunsheng, et.al. (2019). Business flexibility does not play as moderator, but as an antecedent of business resilience. Alliance capability influences business resilience directly. It is relevant with previous studies (Scholten \& Schilder, 2015; Medel, Kousar, \& Masood, 2020; Dubey, et. al., 2021). Alliance capability or strategic collaboration with other institutions will impact the resilience. For developing business resilience, owner and/or manager of SME could do rational thing, such as doing business more flexibly (business flexibility) and conducting more strategic alliance with other institutions (alliance capability). Beside rational things, business resilience can be leveraged by intensifying workplace spirituality as an irrational approach. It supports the previous studies (Shelton, Hein, \& Phipps, 2019; Esievo, Oshi, Hettey, \&Tende, 2019), Although it is perceived as indirect and illogical, this study proved that spiritual activities at workplace can affect directly, positively, and significantly on business resilience.

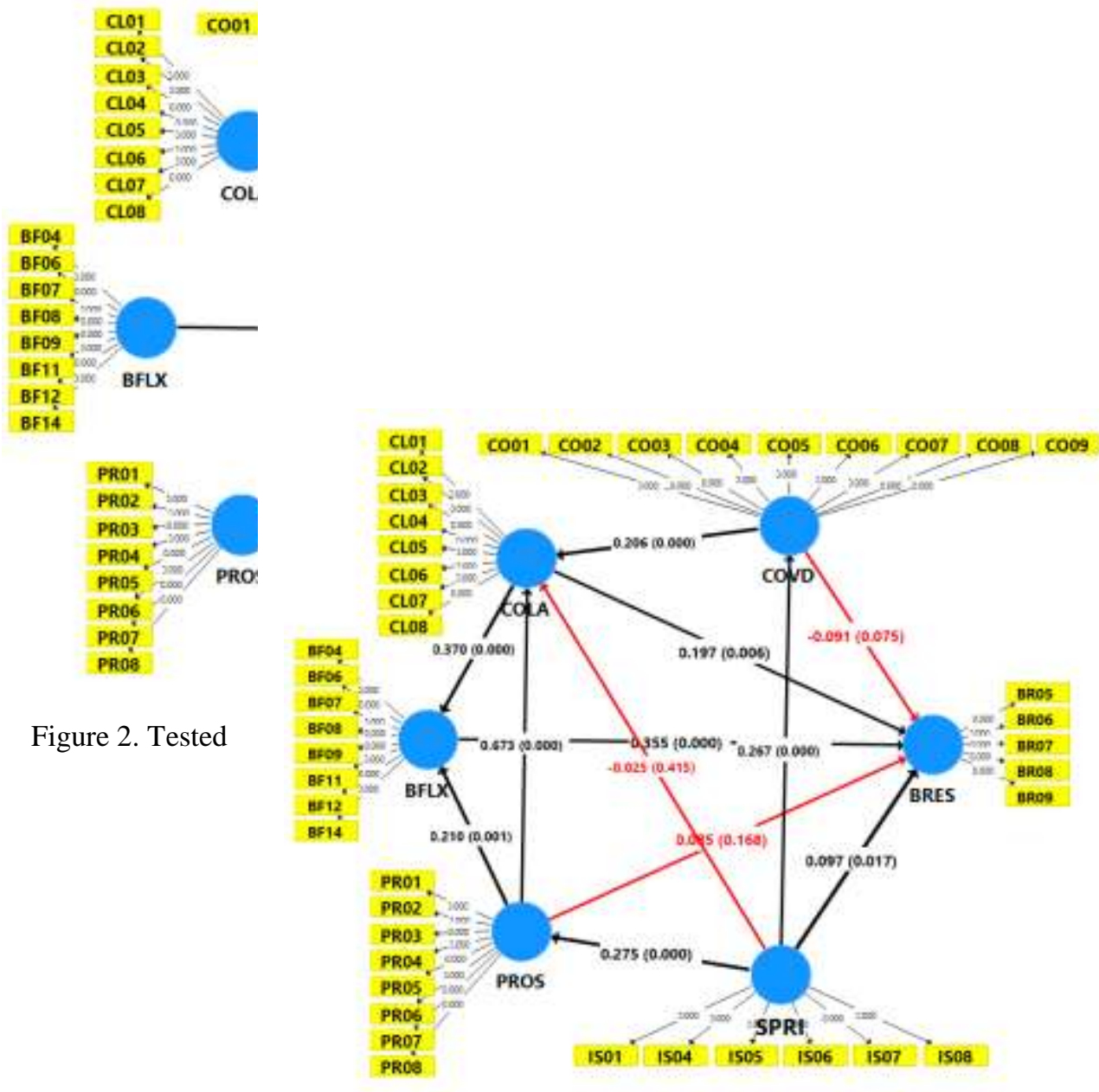

Research Model 
For further elaboration, the research model is extended by adding more other relationships among variables. Figure 2 shows the tested and extended research model. Based on bootstrapping calculation of PLS SEM, Figure 1 demonstrates the result. In extended model, COVID-19 health protocol (COVD) and prosocial leadership (PROS) does not impact on business resilience directly, but they do indirectly. COVID-19 health protocol influence alliance capability, then alliance capability impacts on business resilience. Alliance capability plays a mediating role in relationship between COVID-19 health protocol and business resilience. It is happened too with pro-social leadership. Pro-social leadership influences business flexibility and alliance capability firstly, then business flexibility and alliance capability simultaneously influence business resilience. Business flexibility and alliance capability are mediator in the relationship between pro-social leadership and business resilience. The last but not the least, workplace spirituality impact business resilience directly and indirectly too. In indirect relationship, workplace spirituality affects pro-social leadership then pro-social leadership impact on business flexibility and alliance capability. Finally, business flexibility and alliance capability influence business resilience.

This study has several limitations. The sampling method is non-probabilistic and not ideally distributed based on the proportion of location and scale of business. Further study of paradox theory needs to be done to get a more appropriate perspective to discuss aspects of rationality and irrationality. Data analysis can use Covariance Based SEM to get a better comparison. Multi group analysis can be added to sharpen the analysis related to different profiles and their effect on the research model. For further research, it is recommended to elaborate other influential factors - either in the scope of individual, group, and organizational level as the independent variables. Several suspected factors on business resilience are digital competence and personal perseverance (individual factors), entrepreneurial leadership (group factor), knowledge management and learning culture (organizational level).

\section{Conclusions}

In dealing with crises such as the COVID-19 pandemic, the owners and/or managers of SMEs can do many things to improve business resilience. Those can be something rational or something that seems irrational. Two rational factors that directly influence business resilience are business flexibility and alliance capability. By increasing business flexibility using digital technology as well as enhancing alliance capability, those will have a direct, positive, and significant impact on business resilience. While the 
application of health protocols in business practice is indeed effective for reducing the spread of COVID-19, but unfortunately does not appear to have a significant effect on business resilience in a micro and small scale of business.

Meanwhile, related to factors that seem irrational, the owners and/or managers of SMEs may intensify workplace spirituality for strengthening business resilience. Workplace spirituality also impact directly on pro-social leadership and the application of health protocols. Although, it does not have a direct impact on business resilience, pro-social leadership has a positive and direct influence on business flexibility and alliance capability. Furthermore, alliance capability and business flexibility concurrently impact on business resilience. The efforts to increase business resilience in small and medium enterprises have double-sided approaches which may be conduct simultaneously. By developing business flexibility and alliance capability as rational side approach and by promoting workplace spirituality as irrational approach.

\section{References}

Aldianto, L., Anggadwita, G., Permatasari, A., Mirzanti, I. R., \& Williamson, I. O. (2021). Toward a Business Resilience Framework for Startups. Sustainability, 13(6), 3132.

Bartik, A. W., Bertrand, M., Cullen, Z., Glaeser, E. L., Luca, M., \& Stanton, C. (2020). The impact of COVID-19 on small business outcomes and expectations. Proceedings of the National Academy of Sciences, 117(30), 17656-17666.

Beninger, S., \& Francis, J. N. (2021). Resources for Business Resilience in a Covid-19 World: A Community-Centric Approach. Business Horizons. https://doi.org/10.1016/j.bushor.2021.02.048

Bryce, C., Ring, P., Ashby, S., \& Wardman, J. K. (2020). Resilience in the face of uncertainty: early lessons from the COVID-19 pandemic. Journal of Risk Research, 23(7-8), 880-887.

Castro, M. P., \& Zermeño, M. G. G. (2020). Being an entrepreneur post-COVID-19-resilience in times of crisis: a systematic literature review. Journal of Entrepreneurship in Emerging Economies. Vol. ahead-of-print No. ahead-ofprint. https://doi.org/10.1108/JEEE-07-2020-0246

Cunha, M. P. E., \& Putnam, L. L. (2019). Paradox theory and the paradox of success. Strategic organization, 17(1), 95106.

Chunsheng, L., Wong, C. W., Yang, C. C., Shang, K. C., \& Lirn, T. C. (2019). Value of supply chain resilience: roles of culture, flexibility, and integration. International Journal of Physical Distribution \& Logistics Management. Vol. 50 No. 1, pp. 80-100. https://doi.org/10.1108/IJPDLM-02-2019-0041

Dimas, I. D., Rebelo, T., Lourenço, P. R., \& Pessoa, C. I. P. (2018). Bouncing back from setbacks: On the mediating role of team resilience in the relationship between transformational leadership and team effectiveness. The Journal of psychology, 152(6), 358-372.

Dubey, R., Gunasekaran, A., Childe, S. J., Fosso Wamba, S., Roubaud, D., \& Foropon, C. (2021). Empirical investigation of data analytics capability and organizational flexibility as complements to supply chain resilience. International Journal of Production Research, 59(1), 110-128.

Esievo, F. K., Oshi, J. E. O., Hettey, H. D., \& Tende, F. B. (2019). Workplace spirituality and organizational resilience of shipping companies in Rivers State. Scholarly Journal of Business Administration, 8(3), 45-51.

Ewest, T. (2017). Prosocial leadership: Understanding the development of prosocial behavior within leaders and their organizational settings. Springer.

Franken, E., Plimmer, G., \& Malinen, S. (2020). Paradoxical leadership in public sector organisations: Its role in fostering employee resilience. Australian Journal of Public Administration, 79(1), 93-110.

Gatling, A., Kim, J. S., \& Milliman, J. (2016). The relationship between workplace spirituality and hospitality supervisors' work attitudes: A self-determination theory perspective. International Journal of Contemporary Hospitality Management.

Gomes-Casseres, B. (1997). Alliance strategies of small firms. Small Business Economics, 9(1), 33-44.

Gourinchas, P. O., Kalemli-Özcan, S.., Penciakova, V., \& Sander, N. (2020). Covid-19 and SME failures (No. w27877). National Bureau of Economic Research.

Holling, C. S. (1973). Resilience and stability of ecological systems. Annual review of ecology and systematics, 4(1), 123.

Jain, S., Kashiramka, S., \& Jain, P. K. (2020). Strategic flexibility through cross-border acquisitions: market response in Indian context. In Transforming Organizations Through Flexible Systems Management (pp. 19-31). Springer, Singapore. 
Kementerian Kesehatan (2020). Decree of the Minister of Health Number HK.01.07/Menkes/382/2020 on Health Protocol for the Community in Places and Public Facilities in the Framework of Prevention and Control of Corona Virus Disease 2019 (Covid-19).

Kohtamäki, M., Rabetino, R., \& Möller, K. (2018). Alliance capabilities: A systematic review and future research directions. Industrial Marketing Management, 68, 188-201.

Korber, S., \& McNaughton, R. B. (2017). Resilience and entrepreneurship: a systematic literature review. International Journal of Entrepreneurial Behavior \& Research. Vol. 24 No. 7, pp. 1129-1154. https://doi.org/10.1108/IJEBR-102016-0356

Kurtz, D. J., \& Varvakis, G. (2016). Dynamic capabilities and organizational resilience in turbulent environments. In Competitive strategies for small and medium enterprises (pp. 19-37). Springer, Cham.

Lee, C. Y., \& Huang, Y. C. (2012). Knowledge stock, ambidextrous learning, and firm performance. Management Decision. Vol. 50 No. 6, pp. 1096-1116. https://doi.org/10.1108/00251741211238355

Lengnick-Hall, C. A., \& Beck, T. E. (2003, August). Beyond bouncing back: The concept of organizational resilience. In National Academy of Management meetings, Seattle, WA.

Libert, B., Beck, M., \& Wind, J. (2016). The network imperative: How to survive and grow in the age of digital business models. Harvard Business Review Press.

Lorenzi, P. (2004). Managing for the common good: prosocial leadership. Organizational dynamics, 33(3), $282-291$.

Medel, K., Kousar, R., \& Masood, T. (2020). A collaboration-resilience framework for disaster management supply networks: a case study of the Philippines. Journal of Humanitarian Logistics and Supply Chain Management. Vol. 10 No. 4, pp. 509-553. https://doi.org/10.1108/JHLSCM-09-2019-0066

Miroshnychenko, I., Strobl, A., Matzler, K., \& De Massis, A. (2020). Absorptive capacity, strategic flexibility, and business model innovation: Empirical evidence from Italian SMEs. Journal of Business Research. Vol 130, pp. 670-682 Niesten, E., \& Jolink, A. (2015). The impact of alliance management capabilities on alliance attributes and performance: a literature review. International journal of management reviews, 17(1), 69-100.

Păunescu, C., \& Mátyus, E. (2020). Resilience measures to dealing with the COVID-19 pandemic Evidence from Romanian micro and small enterprises. Management \& Marketing. Challenges for the Knowledge Society, 15(s1), 439457.

Petchsawang, P., \& McLean, G. N. (2017). Workplace spirituality, mindfulness meditation, and work engagement. Journal of Management, Spirituality \& Religion, 14(3), 216-244.

Osofsky, H. J., Weems, C. F., Graham, R. A., Osofsky, J. D., Hansel, T. C., \& King, L. S. (2019). Perceptions of resilience and physical health symptom improvement following post disaster integrated health services. Disaster medicine and public health preparedness, 13(2), 223-229.

Ower, C., Kemmler, G., Vill, T., Martini, C., Schmitt, A., Sperner-Unterweger, B., \& Hüfner, K. (2019). The effect of physical activity in an alpine environment on quality of life is mediated by resilience in patients with psychosomatic disorders and healthy controls. European archives of psychiatry and clinical neuroscience, 269(5), 543-553.

Rezapouraghdam, H., Alipour, H., \& Arasli, H. (2019). Workplace spirituality and organization sustainability: a theoretical perspective on hospitality employees' sustainable behavior. Environment, Development and Sustainability, 21(4), 1583-1601.

Sabatino, M. (2016). Economic crisis and resilience: Resilient capacity and competitiveness of the enterprises. Journal of Business Research, 69(5), 1924-1927.

Scholten, K., \& Schilder, S. (2015). The role of collaboration in supply chain resilience. Supply Chain Management: An International Journal. Vol. 20 No. 4, pp. 471-484. https://doi.org/10.1108/SCM-11-2014-0386

Shelton, C. D., Hein, S., \& Phipps, K. A. (2019). Resilience and spirituality: A mixed methods exploration of executive stress. International Journal of Organizational Analysis. Vol. 28 No. 2, pp. 399-416. https://doi.org/10.1108/IJOA-082019-1848

Surya, B., Menne, F., Sabhan, H., Suriani, S., Abubakar, H., \& Idris, M. (2021). Economic Growth, Increasing Productivity of SMEs, and Open Innovation. Journal of Open Innovation: Technology, Market, and Complexity, 7(1), 20.

Swanson, A., Geller, J., DeMartini, K., Fernandez, A., \& Fehon, D. (2018). Active coping and perceived social support mediate the relationship between physical health and resilience in liver transplant candidates. Journal of clinical psychology in medical settings, 25(4), 485-496.

Tsilika, T., Kakouris, A., Apostolopoulos, N., \& Dermatis, Z. (2020). Entrepreneurial bricolage in the aftermath of a shock. Insights from Greek SMEs. Journal of Small Business \& Entrepreneurship, 32(6), 635-652. 
Volberda, H. W. (1996). Toward the flexible form: How to remain vital in hypercompetitive environments. Organization science, 7(4), 359-374.

Waldman, D. A., Putnam, L. L., Miron-Spektor, E., \& Siegel, D. (2019). The role of paradox theory in decision making and management research. Organizational Behavior and Human Decision Processes, 155, 1-6.

Zhu, Y., Zhang, S., \& Shen, Y. (2019). Humble leadership and employee resilience: exploring the mediating mechanism of work-related promotion focus and perceived insider identity. Frontiers in psychology, $10,673$. 